\title{
A utilização do lúdico para a aprendizagem do conteúdo de genética
}

\author{
Carla Regina de Mendonça dos Santos ${ }^{1}$ \\ Paulo Roberto Queiroz da Silva²
}

\section{Resumo}

Os conceitos abordados no ensino de Genética são, geralmente, de difícil assimilação, sendo necessárias práticas que auxiliem no aprendizado dos alunos. Tais atividades, quando aplicadas de forma lúdica, complementam o conteúdo teórico permitindo maior interação entre conhecimento-professor-aluno, trazendo contribuições ao processo ensino-aprendizagem. Este trabalho tem como objetivo apresentar os conceitos básicos de genética aos alunos do Ensino Médio de uma escola pública do Distrito Federal, por meio de atividades lúdicas aplicadas aos alunos do terceiro ano. Os 89 alunos participantes responderam a um questionário com a função de avaliar o conhecimento prévio deles a respeito do assunto. Para que o projeto fosse viável economicamente, os jogos foram elaborados com materiais encontrados no cotidiano e que são de baixo custo. Foram aplicados três jogos: o jogo do cariótipo, o jogo do DNA e o jogo do dominó. Ao final do trabalho, foi aplicado um segundo questionário para verificar se os alunos aprenderam com os jogos. Dessa forma, o trabalho procurou aplicar formas diferentes de ensinar o conteúdo de Genética, além de promover um melhor relacionamento entre alunos e aluno-professor, deixando as aulas mais dinâmicas e descontraídas.

Palavras-chave: Metodologia de ensino. Lúdico. Biologia. Genética.

\section{Introdução}

A educação é um processo inerente ao desenvolvimento do ser humano e, portanto, constitui-se em parte integrante de sua existência, presente na formação

1 Licenciada em Biologia pelo Centro Universitário de Brasília - UniCEUB. crmendonca@ gmail.com

2 Professor do curso de Biomedicina do UniCEUB. Doutor em Biologia Animal pela UnB. paulo.silva@uniceub.br 
de hábitos, atitudes, valores, aquisição de conhecimentos e esquemas de raciocínio que vão traçar as linhas mestras de sua personalidade, uma estrutura básica de esquemas de adaptação no decorrer do seu desenvolvimento. Sendo assim, por meio da aplicação de atividades lúdicas, pode-se viabilizar o aumento do rendimento, possibilitando o seu desenvolvimento enquanto cidadãos e agentes do meio em que vivem (OLENIKI, 2002).

Nas últimas décadas, temos observado que os professores consideram a ludicidade como uma estratégia viável que se adapta às novas exigências da educação. O problema está em saber como os professores encaram o lúdico nas suas atividades de ensino (HERMAN, 2007). Segundo Bueno (1999), o jogo tem uma função vital para o indivíduo porque faz parte integrante da vida em geral, não só para liberar a tensão e descarregar energia, mas principalmente como forma de assimilação da realidade, além de ser culturalmente útil para a sociedade como expressão de ideais comunitários.

É brincando e jogando que as pessoas trabalham o raciocínio lógico: elas pensam, analisam e calculam qual seria o passo mais certo para determinada jogada, lembrando que todo jogo tem regras que não podem ser burladas. Com o processo de elaboração da jogada, utilizam-se melhor os conhecimentos e habilidades, conforme o tipo de inteligência do jogador.

De acordo com Santos (2001), os professores fazem algumas perguntas sobre: Por que se joga? Onde se joga? Quando se joga? Como se joga? São questões que se encontram, ainda hoje, no itinerário escolar, e as respostas a esses questionamentos são as molas propulsoras que a literatura tem mostrado que é possível ensinar sem entediar, e que o jogo é um recurso de aprendizagem mais eficaz para a construção do conhecimento, independentemente da idade cronológica do aluno.

No decorrer do desenvolvimento do indivíduo, ocorre um declínio do brinquedo, representado pelo jogo de papéis, de faz de conta, abrindo um espaço cada vez maior para o jogo de regras. No surgimento do jogo de regras, os elementos estruturais do brinquedo são absorvidos e novas transformações ocorrem, promovendo o desenvolvimento dos processos psicológicos (DAGOSTIN, 2004). 
Conforme Herman (2007), vale lembrar que, quando se fala de jogo na educação, ele tem uma conotação diferente daquele conceito que prevaleceu por muito tempo no Brasil, no qual a competição e as regras fixas eram os aspectos que o diferenciavam das brincadeiras. Trata-se o jogo, hoje, de forma bem mais abrangente. Nesse sentido, tanto pode ser competição, como apenas representar uma ação lúdica. Contudo, é a ludicidade que dá o caráter de jogo às atividades escolares. Santos (2001) ressalta ainda a ideia de que é preciso que os profissionais de educação reconheçam o real significado do lúdico para aplicá-lo adequadamente, estabelecendo a relação entre o brincar e o aprender a aprender.

O lúdico, quando utilizado pelo professor como estratégia de ensino, deve trazer curiosidade, prender a atenção, instigar os alunos a se interessarem pelo que está sendo proposto, facilitando a compreensão do conteúdo lecionado, deixando-os entretidos, curiosos e concentrados. Dessa forma, eles irão pesquisar, tirar suas dúvidas e, principalmente, terão facilitada a compreensão do conteúdo lecionado e ficarão mais interessados pelas aulas.

Conforme Patrinhani (2001), acredita-se que, por meio das atividades lúdicas aliadas a um trabalho consciente do professor, o aluno mostra-se mais dinâmico, organizado, atencioso, desinibido, concentrado e ágil em seu raciocínio lógico. Assim, pode-se dizer que o jogo possibilita a construção interior do mundo do sujeito, pois jogar é a forma mais espontânea de entrar em contato com a realidade. É desafiar o novo; e a novidade é fundamental para despertar a realidade que envolve o ser humano.

E como concretizar essa aprendizagem permeada pelo lúdico? Esse é um grande desafio para os professores. Segundo Hauer (2005), o jogo pode se confundir, por vezes, com o próprio trabalho - principalmente no caso do trabalho espontâneo - e a atividade lúdica pode se revestir da mais profunda seriedade.

Cunha (2000) destaca que a educação lúdica deve estar distante da concepção de passatempo, brincadeira e diversão superficial. Ela é uma ação inerente e aparece sempre como forma transacional em direção a algum conhecimento que se 
redefine na elaboração constante do pensamento individual em permutações com o pensamento coletivo.

Os conhecimentos na área de Genética são de natureza interdisciplinar e apresentam relação direta com o contexto social contemporâneo. A sociedade necessita ter acesso aos conhecimentos científicos dessa área, para que possa se engajar em um debate informado sobre o futuro das pesquisas em Genética e como sua aplicação pode afetar a saúde humana e o ambiente (KLAUTAU-GUIMARÃES et al., 2008).

Os conceitos abordados no ensino de Genética são geralmente de difícil assimilação, sendo necessárias práticas que auxiliem no aprendizado dos alunos. Dessa forma, métodos inovadores de ensino que envolvam arte, modelos e jogos mostram-se promissores para serem aplicados no ensino dessa disciplina científica. Tais atividades, quando aplicadas de forma lúdica, complementam o conteúdo teórico permitindo maior interação entre conhecimento-professor-aluno, trazendo contribuições ao processo ensino-aprendizagem. Para Miranda (2001), o fato de o jogo ser lúdico, divertido e prazeroso o torna uma das formas mais eficazes de ensino, sendo uma estratégia para melhorar o desempenho dos alunos em conteúdos de difícil aprendizagem.

Segundo Bortoloto e Felício (2003), a Genética está cada vez mais inserida no cotidiano social, seja nas revistas, jornais, noticiários e, até mesmo, em novelas e programas populares. Mesmo assim, o assunto é visto com frequência na sala de aula de forma teórica e tradicional. A maioria dos professores de Biologia transforma a aula em uma sequência de possíveis combinações entre as letras que correspondem aos genes, sem que os alunos compreendam o que é um gene e como ele se comporta de geração para geração. Depois disso, a aula se transforma em sucessivos cálculos de frações e porcentagens para determinar as chances de um indivíduo possuir ou não um caráter hereditário.

O professor deve auxiliar na tarefa de formulação e de reformulação de conceitos ativando o conhecimento prévio dos alunos com uma introdução da matéria que se articule à nova informação que está sendo apresentada e utilizando recursos didáticos para facilitar a compreensão do conteúdo pelo aluno (POZO, 1998). 
Segundo Gadotti (1993), a criança e mesmo o jovem apresentam uma resistência à escola e ao ensino porque, acima de tudo, a escola não é lúdica, não é prazerosa. O lúdico apresenta valores específicos para todas as fases da vida humana. Assim, na infância e na adolescência, o jogo, o lúdico, poderia ter uma finalidade, antes de tudo, pedagógica. Dessa forma, o jogo, como atividade lúdica, poderia ser utilizado para complementar as atividades teóricas.

Para Miranda (2001), o fato de o jogo ser divertido e prazeroso caracteriza-o como uma das formas mais eficazes de ensino, podendo ser utilizado como uma estratégia para melhorar o desempenho dos estudantes em conteúdos mais complexos. O jogo representa uma importante ferramenta educacional e pode auxiliar o trabalho pedagógico nos diferentes níveis de ensino, nas diversas áreas do conhecimento, tanto em sala de aula como até mesmo fora dela.

Muitos alunos têm dificuldades para entender diferentes temas biológicos, o que compromete o estabelecimento e a visualização de relações entre tais assuntos. Por outro lado, a relação professor-aluno, na qual o primeiro atua como transmissor e o segundo apenas como receptor, não desperta interesse, não proporciona ao aluno construir seu conhecimento, o que pode ser obtido com o uso de abordagens lúdicas, utilizando jogos ou maquetes (BOLELI et al., 2004).

Segundo Giacoia (2006), esse fato se torna um problema quando o conteúdo de genética é ministrado de forma compartimentalizada; não se pode dizer que elimine o interesse do aluno, mas torna seu entendimento muito mais difícil e, muitas vezes, distorcido. De acordo com Justina (2001), quando o conhecimento científico é abordado de forma não fragmentada, desmistificada e histórica, pode ser grande a sua contribuição para efetiva compreensão pelos estudantes do Ensino Médio dos limites e aplicações dos avanços científicos.

Como exemplo para reforçar a importância da aplicação das atividades dinâmicas como estratégia de ensino, Wasko et al. (2007) destacaram em seu trabalho a peça de teatro "Jornal Corporal", uma das diversas atividades que foram geradas durante a realização de uma oficina de Biologia. Essa proposta de dramatização configurou excelente material didático para ser explorado no Ensino Médio nas 
aulas de Genética e Biologia Celular e apresentou, de forma criativa e dinâmica, diversos conceitos dessas áreas que são comumente abordadas como conteúdos específicos da grade curricular.

Dessa forma, pode-se ensinar de maneira mais humanizada, respeitando as culturas e os valores dos alunos participantes (BORGES-NETO, 1998). Segundo Justiniano et al. (2009), por meio de atividades lúdicas pedagógicas, é possível desenvolver o senso de organização, o espírito crítico e competitivo, o respeito mútuo e a fixação do conteúdo com maior facilidade. A utilização de jogos como ferramenta pedagógica auxilia na exposição como também na fixação dos diversos assuntos abordados durante as aulas.

Verifica-se, na maior parte das escolas de Ensino Fundamental e Médio no Brasil, a falta de interconexão entre conteúdos que deveriam ser complementares. Um exemplo disso é a prática, em diversos estados do país, de apresentar a divisão celular - mitose e meiose - no primeiro ano do Ensino Médio e a genética no terceiro ano. Os estudantes não são orientados para estabelecer as devidas relações entre esses assuntos e chegam ao ensino superior com erros conceituais e sem conseguirem fazer as correlações entre esses conteúdos. Como consequência dessa situação, a maioria não consegue fazer a correlação direta entre divisão celular, perpetuação da vida e transmissão de características. Além disso, apresentam falta de entendimento dos conceitos de locus gênico e alelos (SALIM et al., 2007).

Conforme Campanario e Moya (1999), várias são as dificuldades identificadas que se relacionam com o processo de aprendizagem às ciências que poderíamos denominar de clássicas, entre elas estariam a estrutura lógica dos conteúdos conceituais, o seu nível de exigência formal, e a influência dos conhecimentos prévios e preconcepções dos alunos. Nos últimos anos, presta-se cada vez mais atenção a fatores como as concepções epistemológicas dos alunos, suas estratégias de raciocínio ou a metacognição.

O estudo da Genética é de difícil compreensão para os alunos do Ensino Médio, devido aos conceitos que não são aplicáveis no seu cotidiano. Com isso, os jogos lúdicos têm como função facilitar a compreensão de tais conceitos, deixando 
as aulas mais dinâmicas e podendo atingir diversos tipos de inteligências, além de ser um meio de aproximação dos alunos com seus colegas e professores. Os jogos lúdicos voltados ao estudo da Genética têm que ser feitos de uma forma descontraída que venha a facilitar, sem utilizar conceitos específicos ou abrangentes demais, para que o aluno compreenda como funcionam os genes, quais são suas funções, além de visualizar o que difere um indivíduo do outro. Com isso, o jogo tem que ser voltado ao cariótipo, observando que pequenas diferenças no gene poderão acarretar grandes diferenças físicas. As atividades lúdicas vêm para facilitar o aprendizado, não se desprendendo dos principais conceitos de Genética, levando o aluno a conhecer novas formas de aprendizado e abrindo assim um horizonte a mais na sua formação.

Este trabalho tem como objetivo apresentar os conceitos básicos de genética aos alunos do ensino médio de uma escola pública do Distrito Federal por meio de atividades lúdicas.

\section{Material e método}

\subsection{O local de aplicação do projeto}

O projeto foi aplicado em uma escola pública do Distrito Federal localizada na cidade-satélite do Cruzeiro Novo.

\subsection{Comitê de Ética em Pesquisa}

Após a autorização do responsável legal pela escola, por meio de assinatura da folha de rosto (FR - 287376) e aprovação pelo comitê de ética do UniCEUB (Protocolo de Pesquisa no TCC 20/09 - CAAE 1174/09, em 10 de setembro de 2009, entregou-se o Termo de Consentimento livre e esclarecido aos alunos para que fossem informados a respeito das atividades a serem realizadas no projeto e manifestassem a sua anuência, ou não, em participar. Ao final dessa fase, foram cadastrados alunos na faixa etária entre 16 e 18 anos do terceiro ano do Ensino Médio que participaram de todas as etapas seguintes do Projeto Socioeducativo, realizado no período de 11 de setembro a 20 de outubro de 2009. 
Aplicou-se um questionário de conhecimentos específicos objetivando avaliar o nível de conhecimento prévio dos alunos, para poder ser dada, então, uma aula reforçando os principais conceitos de genética.

\subsection{A confecção e montagem dos jogos aplicados}

\subsubsection{Jogo do cariótipo}

Primeiramente, o conteúdo e o objeto de estudo do Projeto foram apresentados tanto por meio de aulas expositivas quanto por meio visual. Em seguida, os participantes foram divididos em quatro grupos, e o modelo do jogo, montado de acordo com as orientações do pesquisador responsável, foi entregue a eles. O jogo de montagem do cariótipo foi utilizado visando explorar os conceitos de cromossomos metacêntricos, submetacêntricos e acrocêntricos que são encontrados na espécie humana. Os alunos executaram as atividades solicitadas e, no final delas, houve um debate para discutir se foi ou não atingido o objetivo da aula.

A confecção do jogo e a montagem do cariótipo foi feita em material emborrachado da seguinte forma: utilizou-se uma folha de EVA na cor branca, de 50 $\mathrm{cm}$ de largura por $40 \mathrm{~cm}$ de altura. Foram desenhadas 10 retas verticais que dividiram a folha em sete quadrantes. O primeiro quadrante possuía duas retas de $10 \mathrm{~cm}$ de altura com o espaço entre elas de $22 \mathrm{~cm}$ de largura. Entre o primeiro e o segundo quadrantes, deixou-se um espaço de $8 \mathrm{~cm}$. O segundo quadrante possuía duas retas de $10 \mathrm{~cm}$ de altura com o espaço entre elas de $17 \mathrm{~cm}$ de largura. $\mathrm{O}$ terceiro quadrante possuía duas retas de $10 \mathrm{~cm}$ de altura com o espaço entre elas de $47 \mathrm{~cm}$ de largura. $\mathrm{O}$ quarto quadrante possuía duas retas de $8 \mathrm{~cm}$ de altura com o espaço entre elas de $18,3 \mathrm{~cm}$ de largura. Entre o quarto e o quinto quadrantes deixou-se um espaço de $10 \mathrm{~cm}$ de largura. O quinto quadrante possuía duas retas de $8 \mathrm{~cm}$ de altura com o espaço entre elas de $18,5 \mathrm{~cm}$ de largura. O sexto quadrante possuía duas retas de $8 \mathrm{~cm}$ de altura com o espaço entre elas de 25,3 cm de largura. Entre o sexto e o sétimo quadrantes houve um espaço de $10 \mathrm{~cm}$ de largura e o sétimo quadrante possuía duas retas de $6,5 \mathrm{~cm}$ de altura com espaço entre elas de 11,4 cm de largura. No meio de cada quadrante, colou-se uma tira de velcro dupla face da cor preta, no mesmo tamanho do seu espaço. 
O primeiro e o terceiro quadrantes foram destinados para os cromossomos metacêntricos e o segundo, para os cromossomos submetacêntricos. O quarto quadrante, para os cromossomos acrocêntricos intermediários, e o quinto quadrante destinou-se para os cromossomos metacêntricos, submetacêntricos e acrocêntricos. No sexto quadrante, ficaram os cromossomos metacêntricos pequenos e no sétimo e último quadrantes, os cromossomos acrocêntricos menores - incluindo os cromossomos sexuais (Figura 1).

Figura 1 - Jogo do cariótipo montado em folha de EVA, indicando os sete quadrantes para a distribuição dos cromossomos humanos.

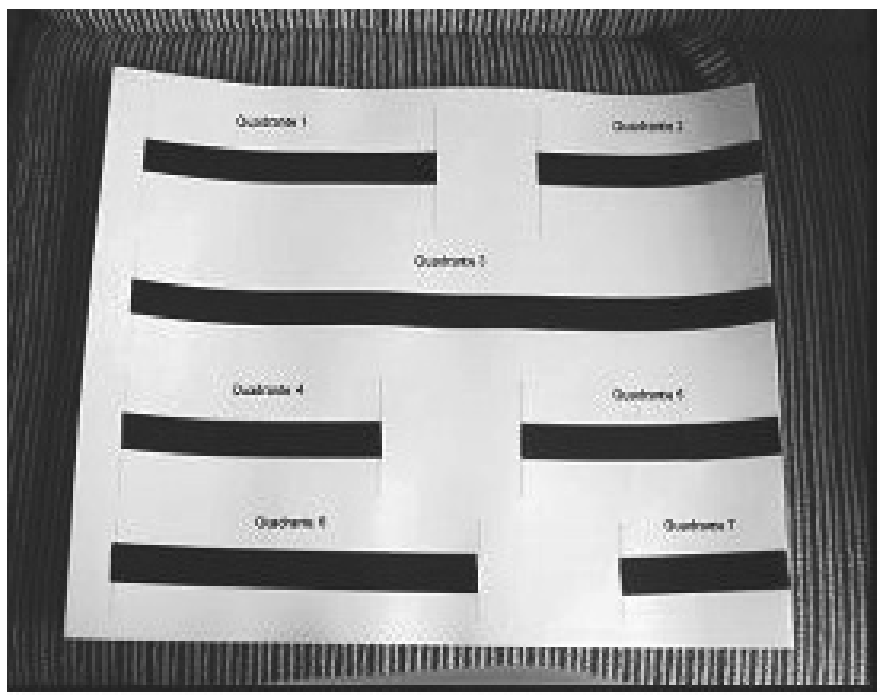

Fonte: Mendonça (2009).

\subsubsection{Jogo do DNA}

O jogo de quebra-cabeça foi utilizado visando desenvolver os conceitos relacionados ao DNA, duplicação, replicação e pareamento entre bases nitrogenadas. Os alunos foram divididos em quatro grupos. Seguindo o comando das atividades pelo pesquisador do projeto, executaram as atividades solicitadas e, no fim da aula, houve um debate para discutir se foi ou não atingido o objetivo proposto.

A confecção do quebra-cabeça foi feita em material emborrachado de várias cores, montado da seguinte forma: 
- A cor amarela foi designada para a base nitrogenada Adenina (A) e foram utilizadas duas folhas de EVA de $50 \mathrm{~cm}$ de largura por 40 $\mathrm{cm}$ de altura. Nessa folha, foram traçadas retas de $4 \mathrm{~cm}$ de largura por $9,5 \mathrm{~cm}$ de altura;

- A cor branca, para base nitrogenada Timina (T). Foi utilizada uma folha de EVA de $50 \mathrm{~cm}$ de largura por $40 \mathrm{~cm}$ de altura. Nessa folha, foram traçadas retas de $4 \mathrm{~cm}$ de largura por $6 \mathrm{~cm}$ de altura;

- A cor vermelha, para base nitrogenada Uracila (U). Foi utilizada uma folha de EVA de $50 \mathrm{~cm}$ de largura por $40 \mathrm{~cm}$ de altura. O procedimento foi conforme o detalhamento anteriormente citado;

- A cor azul, designada para a base nitrogenada Citosina (C). Foi utilizada uma folha de EVA de $50 \mathrm{~cm}$ de largura por $40 \mathrm{~cm}$ de altura; e

- A cor laranja, para base nitrogenada Guanina (G), sendo utilizadas duas folhas de EVA de acordo com as especificações anteriormente citadas.

Ao final, todas as folhas de EVA com as suas respectivas cores e traços de retas foram, então, cortadas. Para a execução dessa atividade, foi entregue junto com o quebra-cabeça, a tabela com os códons e os nomes dos correspondentes aminoácidos (TURNER et al., 2004).

\subsubsection{Jogo de dominó}

No terceiro jogo, utilizou-se a estratégia de aplicação de um dominó, cuja finalidade é simular os eventos da meiose e a permuta genética. O modelo básico foi fornecido ao grupo de estudantes e montado seguindo-se as orientações do professor, o tempo disponível e o objetivo principal da atividade. O jogo de dominó foi utilizado explorando os conceitos básicos de Genética.

Para o melhor aproveitamento das 28 peças do dominó, foi definida uma composição de $2 \mathrm{n}=14$, sendo que os sete cromossomos de origem paterna foram representados na cor azul e os sete cromossomos de origem materna foram representados na cor vermelha. Cada cromossomo foi representado por duas pe- 
ças, cada peça representando uma cromátide, visando facilitar a visualização da dinâmica da sua separação no processo de divisão celular. Para facilitar o entendimento dos conteúdos que estavam sendo abordados no jogo dos dominós, ficaram disponíveis para consulta vários livros de Biologia e foi previsto um tempo de 20 minutos para a discussão dos resultados.

Os alunos foram divididos em quatro grupos e cada grupo utilizou o dominó de acordo com a atividade correspondente. A confecção do dominó foi em material emborrachado EVA. Para o jogo do ciclo celular normal (meiose) sem crossing-over e segregação independente, o professor solicitou aos alunos que simulassem o comportamento do material genético durante a divisão meiótica, considerando loci de heterozigose. Nesse momento, trabalhou-se somente a combinação entre os diferentes cromossomos homólogos (sem crossing-over). Solicitou-se também que os alunos observassem os produtos (gametas) e questionou-se sobre a ocorrência de diferenças entre os gametas e o porquê disso: Quantos produtos são esperados? Qual a probabilidade de ocorrência de cada um?

A confecção dos cromossomos foi feita da seguinte forma: utilizou-se um dominó de plástico e folhas de EVA da cor branca de $50 \mathrm{~cm}$ de largura por $40 \mathrm{~cm}$ de altura. Nessa folha, foram traçadas retas de 4,3 cm de largura por 2,15 $\mathrm{cm}$ de altura; cortaram-se, então, esses pedaços e, com cola para EVA, eles foram fixados sobre os números do dominó. Em seguida, utilizou-se papel camurça de duas cores diferentes para representar a herança dos cromossomos materno e paterno na forma de cromátides (KLAUTAU-GUIMARÃES et al., 2008).

\subsection{Avaliação final de aprendizado}

Após o término dos jogos em sala de aula, reaplicou-se o questionário duas semanas após a finalização do Projeto para avaliar o nível de fixação dos conteúdos abordados no período. 


\section{Resultados}

\subsection{Avaliação do questionário aplicado no início do projeto}

No primeiro questionário, observou-se que os alunos não tinham os conceitos de genética bem definidos (Figura 2). De acordo com a pergunta número 1, foi solicitado aos alunos que indicassem quantas moléculas de DNA existiam no núcleo das células humanas. Os resultados indicaram que 25\% dos alunos responderam certo, quando disseram que os seres humanos possuem 46 cromossomos e $75 \%$ dos alunos responderam errado. Como exemplo de erro dessa questão, alguns alunos responderam: "2 milhões de cromossomos", “4N", “3 milhões”, “1”, "apenas uma”, "nenhuma” e "depende do tamanho da célula e da saúde da pessoa".

Na pergunta número 2, foi solicitado que os alunos relacionassem os seguintes termos de Biologia: cromossomos, DNA, bases nitrogenadas, cariótipo e gene. Observou-se que $10 \%$ dos alunos relacionaram os termos de Genética de forma correta como: "bases nitrogenadas-DNA-gene-cromossomo-cariótipo"; e 90\% dos alunos não sabiam relacionar os termos da Biologia. Isso foi observado pelas respostas "cromossomos-gene-cariótipo-DNA-bases nitrogenadas", "gene-cromossomo-DNA-cariótipo-bases nitrogenadas".

Na pergunta número 3, observou-se que $25 \%$ dos alunos responderam de forma correta a pergunta a respeito de quais eram os tipos de células envolvidas no processo meiótico e por que esse processo é tão importante para os organismos de reprodução sexuada. Como exemplo de respostas, obteve-se: "são as células sexuais as células que participam do processo meiótico e a sua importância é para manter a variabilidade genética". Entretanto, 75\% dos alunos responderam de forma errada. Como exemplo de respostas inadequadas: "procarionte e eucarionte"; "DNA"; "cromossomos para recriação do DNA"; "células 4 N"; ou, responderam: "sei lá"; "não sei". Percebeu-se que alguns alunos sabiam quais eram as células, mas não sabiam a sua importância na reprodução sexuada; outros sabiam a importância, mas não sabiam quais eram as células.

Na pergunta número 4, os alunos deveriam definir o termo gene. Observou-se que $10 \%$ dos alunos souberam definir o termo gene, ou seja, "uma parte do DNA 
que corresponde a uma proteína". Contudo, $90 \%$ dos alunos não souberam definir o termo. Como exemplo de respostas sem relação com o conteúdo: "gene é o primitivo de Genoveva e também alguma coisa ligado à biologia"; "Gene é o primitivo de Gênova, cidade onde Cristovam Colombo nasceu, portanto Colombo era Genovês"; "É uma coisa que carrega o DNA do indivíduo".

Na última, solicitou-se que os alunos, a partir de uma sequência de fita molde de DNA, fizessem o DNA complementar e, a partir do DNA, fizessem uma fita de RNA. Nesse exercício, observou-se que 50\% dos alunos souberam escrever a fita de DNA complementar a partir da fita molde e transformar essa fita molde em RNA. A fita molde correspondia à sequência: 5' ATT CGC CGA GTT 3; a fita de DNA complementar correta a ser produzida: TAA GCG GCT CAA; a fita de RNA correta: AUU CGC CGA GUU. Observou-se que 50\% dos alunos escreveram a fita de DNA complementar, mas se confundiram na passagem do DNA para RNA. Muitos não relacionaram que a fita de RNA não possuía a base nitrogenada Timina e, sim, Uracila.

Figura 2 - Primeiro questionário aplicado no início do Projeto para avaliar o nível de conhecimento dos alunos ${ }^{3}$

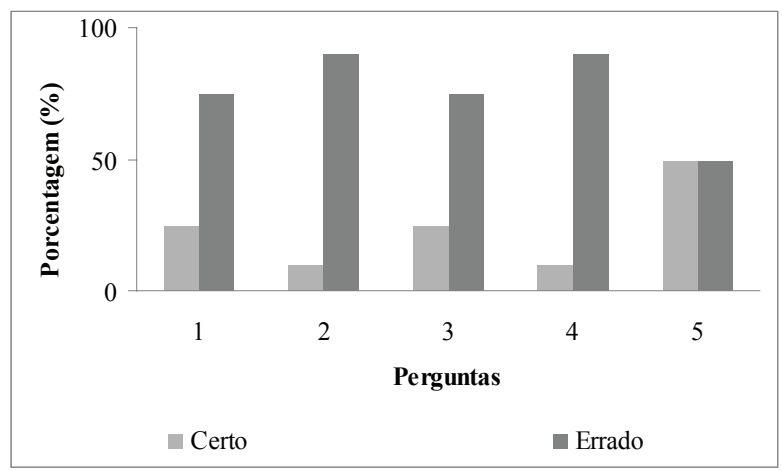

Fonte: Mendonça (2009).

\footnotetext{
3 As perguntas foram as seguintes: 1 ) Quantas moléculas de DNA existem no núcleo das células humanas? 2) Faça um esquema relacionando os seguintes termos: Cromossomos, DNA, Bases Nitrogenadas, Cariótipo e Gene. 3) Quais são os tipos de células que estão envolvidas no processo meiótico? Por que esse processo é tão importante para os organismos de reprodução sexuada? 4) Como você definiria o termo gene? 5) A partir da sequência de fita molde apresentada a seguir: 5' CCG TTA CAT AGC TCG AAA TAT 3', obtenha: a) A fita de DNA complementar; b) A fita de RNA a partir da sequência de DNA complementar.
} 


\subsection{Jogo do cariótipo}

Antes de iniciar as atividades envolvendo os jogos, foram ministradas aulas sobre o conteúdo a ser tratado. Logo após as aulas, os alunos foram divididos em quatro grupos constituídos por um número aleatório de participantes.

Após a formação dos grupos, foram explicados os objetivos de cada atividade e solicitado aos participantes que os jogos fossem montados da forma que achassem que era a correta. Qualquer dúvida que tivessem, poderiam consultar o livro de Biologia, perguntar ao professor ou, até mesmo, chamar um colega de outro grupo para ajudar. A ideia dos jogos era fazer com que os alunos interagissem, se ajudassem e, principalmente, fixassem o conteúdo passado primeiro com uma aula e, depois, com a atividade de montagem do jogo.

No jogo do cariótipo, ministrou-se uma aula sobre cromossomos, suas subdivisões segundo o centrômero, sua disposição no mapa do cariótipo e seu tamanho. Depois, os alunos formaram quatro grupos e receberam as folhas de EVA com as demarcações onde eles deveriam colocar cada cromossomo e quatro saquinhos contendo os cromossomos autossômicos e sexuais.

Para a execução da atividade, foi mostrado para cada grupo como era um cariótipo para que eles entendessem o objetivo do jogo, ou seja, mostrar que não possuíamos cromossomos do mesmo tamanho, metade dos cromossomos era proveniente de um dos parentais e, independente de tamanho, forma e sexo, todos os seres humanos possuem 46 cromossomos.

Inicialmente os alunos montaram de forma incorreta, mas como alguns alunos já haviam entendido o objetivo do jogo foram ajudar os demais colegas, acontecendo a interação, conforme o objetivo da atividade (Figura 3). 
Figura 3 - Atividade de montagem dos cromossomos humanos por meio do jogo do cariótipo ${ }^{4}$

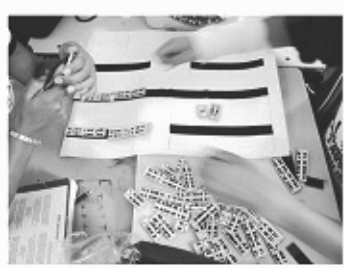

A

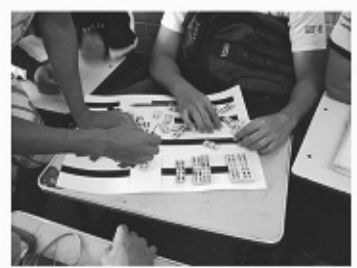

B

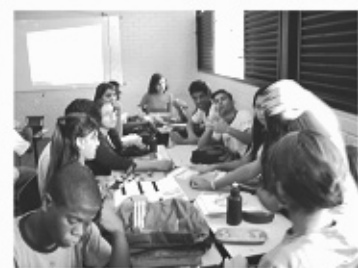

C

Fonte: Mendonça (2009).

\subsection{Jogo do DNA}

No jogo do DNA, também foi ministrada uma aula sobre a molécula de DNA, sua forma em dupla hélice de cadeias antiparalelas; suas bases nitrogenadas: Adenina (A), Timina (T), Citosina (C) e Guanina (G); sua diferença para o RNA; a forma da molécula de RNA; a troca da base nitrogenada Timina para Uracila (U) no RNA; os processos de replicação e transcrição; e a natureza do pareamento entre as bases nitrogenadas.

Em seguida, os alunos formaram novamente quatro grupos e foram fornecidas a eles fichas correspondentes às bases nitrogenadas: na cor branca, Timina; em vermelho, Uracila; na cor laranja, Guanina; na amarela, Adenina; e na azul, Citosina, que serviram para os participantes realizarem o pareamento. Ainda foi entregue aos grupos uma ficha contendo as etapas a serem seguidas.

A maior dificuldade dos alunos foi fazer o pareamento das bases nitrogenadas na carteira, porque só se lembravam do DNA na sua forma helicoidal e disseram que não sabiam montar o DNA na sua forma plana. Da mesma forma que no primeiro jogo, os alunos se ajudaram. O objetivo do jogo foi mostrar aos alunos, de forma prática, como as bases nitrogenadas se encaixavam, como se for-

\footnotetext{
4 Em A, foi oferecido o painel e os cromossomos em EVA; em B, os alunos aplicando o conceito de organização do cariótipo humano; e em $\mathrm{C}$, os alunos discutindo e consultando livros visando resolver as dúvidas para organizar os cromossomos no cariótipo.
} 
mava a fita de DNA complementar e como ocorria a síntese de RNA a partir do DNA (Figura 4).

Figura 4 - Atividade de pareamento das bases nitrogenadas por meio do jogo do DNA ${ }^{5}$.

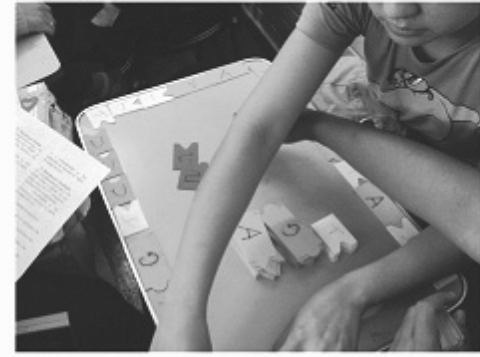

A

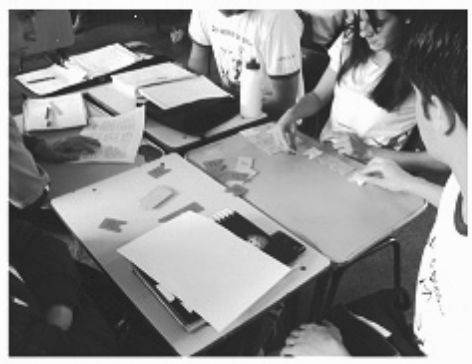

$\mathrm{C}$

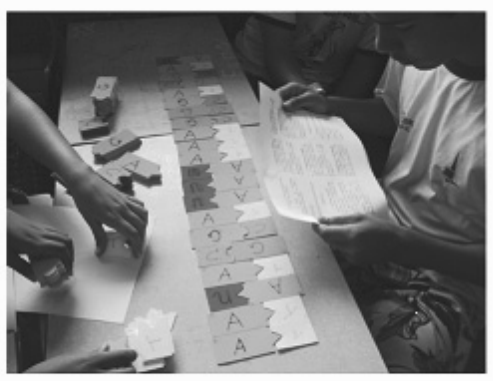

B

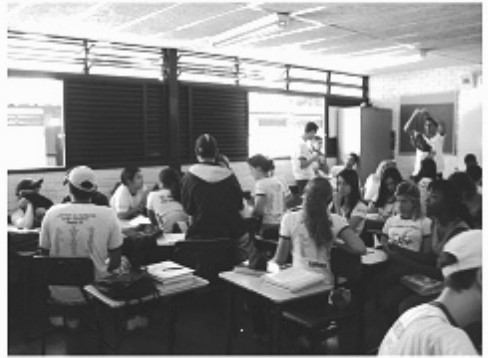

D

Fonte: Mendonça (2009).

\subsection{Jogo do dominó}

Na terceira atividade, o jogo do dominó, como nas demais, também foi ministrada uma aula sobre o conteúdo de meiose.

\footnotetext{
${ }^{5}$ Em A, montagem inadequada da molécula de DNA com os pareamentos; em B, montagem adequada da molécula de DNA com a representação dos pareamentos de bases nitrogenadas; e em C e D, alunos consultando o livro didático e discutindo como resolver as dúvidas na montagem da molécula de DNA com os seus pareamentos de bases corretos.
} 
Para a realização desse jogo, foi utilizado um dominó, sendo que cada cromossomo do mesmo par foi representado por duas peças de dominó de cores diferentes representando as origens parentais desses cromossomos.

Cada peça representou uma cromátide para facilitar a visualização da dinâmica e a separação das cromátides durante o processo de divisão celular. Logo após a aula, os participantes formaram os quatro grupos, constituídos com números aleatórios de alunos e, em seguida, foram distribuídos aos grupos os jogos de dominó. Os alunos simularam o processo de separação das cromátides ao longo da meiose I e II. Havendo dúvidas, os alunos poderiam consultar o professor ou os outros colegas $\mathrm{O}$ objetivo do jogo foi representar na forma prática como ocorre a meiose. Nesse jogo, os alunos não tiveram dúvidas e entenderam a dinâmica da formação do par de cromátides-irmãs e o processo de separação ao longo das fases da meiose até a formação dos gametas (Figura 5).

Figura 5 - Uso do jogo do dominó como atividade para entendimento das etapas da meiose e a formação dos gametas, montagem e distribuição dos cromossomos ao longo das fases da meiose ${ }^{6}$.

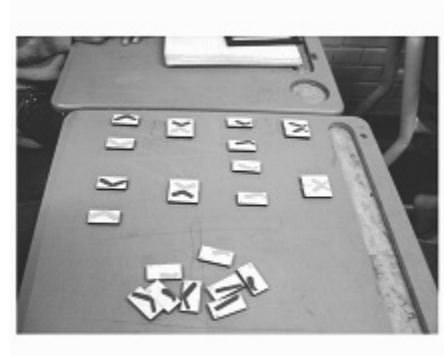

A

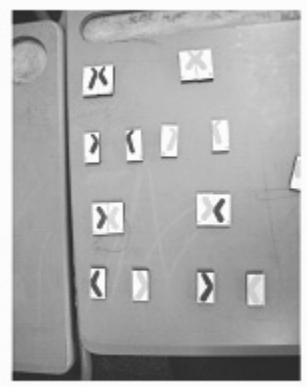

B

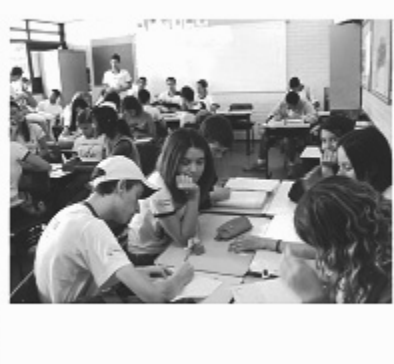

C

Fonte: Mendonça (2009).

${ }_{6}$ Em A e B, montagem do jogo do dominó com a representação da segregação dos cromossomos; em C, atividade conjunta dos alunos visando solucionar dúvidas para a resolução da atividade. 


\subsection{A etapa de finalização do projeto}

O segundo questionário foi reaplicado duas semanas após o término do Projeto. Esse questionário era composto pelas mesmas perguntas que foram aplicadas no início das atividades.. Quando se avaliou a pergunta número 1, a respeito de quantas moléculas de DNA existiam no núcleo das células humanas, observou-se que $89 \%$ da turma acertou a primeira abordagem e, na segunda avaliação, 100\% dos alunos entenderam que os seres humanos possuem 46 cromossomos. Ou seja, por meio das aulas ministradas e dos jogos aplicados, observou-se que todos os alunos entenderam quantos cromossomos compõem o cariótipo humano.

Na pergunta número 2, 95\% dos alunos souberam relacionar os termos básicos de genética e apenas $5 \%$ dos alunos ainda tiveram algum tipo de dúvida. Os alunos não conseguem entender muito bem o que é relacionar os termos do mais simples para o mais complexo. Muitos achavam que o mais simples era o gene por ser como eles diziam "uma parte do DNA", então colocavam gene (DNA) bases nitrogenadas-cariótipo-cromossomos.

Já na pergunta número 3, 82\% dos alunos responderam que as células usadas no processo meiótico são as células sexuais (os gametas) e souberam vincular o papel dessas células com o processo de variabilidade genética. Além disso, 18\% dos participantes disseram que o jogo de dominó ajudou muito. Entretanto, relataram ainda que têm algumas dificuldades no entendimento do processo.

Na pergunta número 4, 68\% dos alunos definiram o termo gene como "uma parte do DNA que corresponde a uma proteína", 32\% dos alunos ainda definem gene como "um pedacinho do DNA que carrega característica".

Na última pergunta, $77 \%$ dos alunos entenderam como ocorre o processo de transcrição, uma vez que conseguiram converter a sequência de DNA (5’ ATT CGC CGA GTT 3) que foi apresentada, no seu DNA complementar (TAA GCG GCT CAA) e, por fim, na molécula de RNA (AUU CGC CGA GUU). Contudo, $23 \%$ dos alunos conseguem fazer o DNA complementar pela fita molde em DNA complementar, mas se confundem na passagem do DNA para o RNA, esquecendo que a fita de RNA não possui a base nitrogenada Timina e, sim, Uracila (Figura 6). 
Figura 6: Comparação entre as respostas produzidas pelos alunos participantes do Projeto Socioeducativo no início e ao final da aplicação das atividades usando jogos

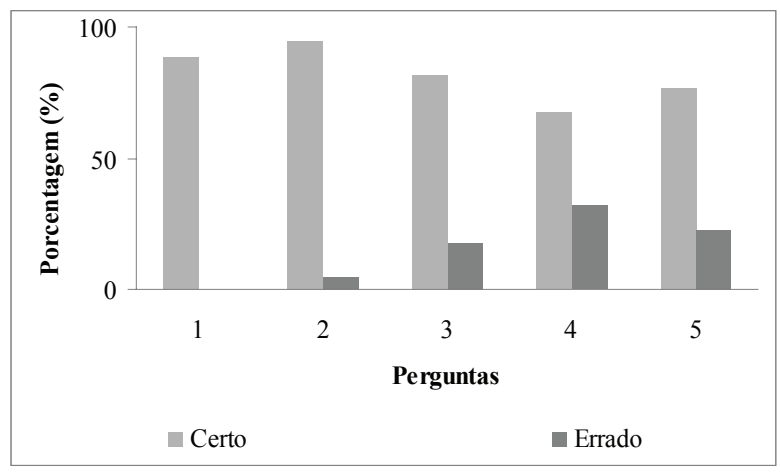

Fonte: Mendonça (2009).

No segundo questionário, foi acrescida uma pergunta extra: Dê sua opinião sobre as atividades realizadas em sala. As atividades ajudaram a entender melhor o conteúdo? As respostas dos alunos foram:

"Sim, as dinâmicas estimularam mais a minha mente e me envolveram mais na aula."

"Sim, me ajudou a entender melhor o conteúdo, pois aprender jogando é bem mais interessante."

"Sim, o método é mais descontraído, fez com que nós assimilássemos mais a matéria."

"Muito produtiva, todos os professores deveriam abordar esse tipo de ensino, pois é mais fácil de entender o conteúdo”.

"Sim, com estas atividades eu compreendi tudo o que não entendia antes."

Por meio dos jogos, eles se sentiram à vontade para ajudar o professor a completar um raciocínio.

\section{Discussão}

Os principais motivos que dificultam a aprendizagem de conceitos e processos biológicos residem no ensino que ignora as concepções prévias dos alunos e res- 
tringe a sua ação à memorização de conteúdos fragmentados e dissociados de sua vida cotidiana, valorizando a reprodução do conhecimento (NUNES et al., 2006).

Quando foi aplicado o primeiro questionário para avaliar o nível de conhecimento prévio dos alunos, observou-se que os conceitos de Genética não estavam claros, ou seja, os alunos não conseguiam relacionar os conteúdos mínimos a respeito do assunto. Isso se deve, em parte, ao desinteresse do aluno em virtude do caráter abstrato do conteúdo e, em alguns casos, da falta de oportunidade de cursos de atualização dos profissionais de ensino e, decisivamente, a falta de recursos e suporte nas escolas para se elaborar e manter esses materiais. Dessa forma, em alguns casos, o professor se vê preso ao livro e ao quadro negro, única e exclusivamente.

Segundo Vigotsky (1988), é papel do professor provocar avanços nos alunos e isso se torna possível com sua interferência na zona proximal. O professor precisa mostrar aos alunos que a matéria ensinada faz parte do cotidiano de todos e, antes de começar a explicar o conteúdo, pode começar perguntando se eles sabem algo que diz respeito ao que irão estudar como, por exemplo, na Genética, qual é a diferença do DNA para o RNA; qual é a função do DNA e do RNA na célula; qual é o impacto do conhecimento dos ácidos nucleicos no cotidiano dos indivíduos e se eles sabem o que quer dizer mitose e meiose. Ou seja, o professor deve procurar meios de estimular e mostrar para os alunos que o conhecimento prévio de determinado assunto ajuda a formar um novo conceito mais aprofundado. Segundo Vigotsky (2001), a aquisição de significados é um processo coletivo, partilhado, feito nas interações em que cada indivíduo se apropria e reconstrói esses significados.

Com a aplicação dos jogos, observou-se que os alunos se interessaram pela forma diferente de ensinar Genética, ao invés de usar o quadro negro. Por exemplo, no primeiro jogo (jogo do cariótipo), pediu-se aos alunos que montassem o cariótipo de um homem e de uma mulher. Dessa forma, eles puderam perceber que, independentemente do sexo, os seres humanos possuem o mesmo número de cromossomos (46 cromossomos). Devido à dinâmica utilizada para ministrar esse conteúdo, percebeu-se que houve uma grande interação da turma: os alunos cooperavam uns com os outros auxiliando os professores, criando condições para o processo de aprendizagem do conteúdo que estava sendo ministrado. Por meio 
da utilização de atividades lúdicas, pôde-se viabilizar o aumento do rendimento, possibilitando o seu desenvolvimento enquanto cidadãos e agentes do meio em que vivem (OLENIKI, 2002).

No jogo do DNA, foi solicitado aos alunos que o montassem e seguissem as etapas do exercício. Muitos tiveram dificuldades por não conhecerem o DNA na sua forma planar didática. Os alunos somente conheciam o DNA na sua forma helicoidal, por isso, não entendiam como montar o DNA na mesa. Nesse jogo, percebeu-se que houve uma maior interação entre os alunos, pois puderam entender como funciona o DNA, como ocorre a mudança de DNA para RNA (a transcrição) e como ocorrem as ligações das bases nitrogenadas (as ligações de hidrogênio entre as bases).

Santos (2001) ressalta ainda a ideia de que é preciso que os profissionais de educação reconheçam o real significado do lúdico para aplicá-lo adequadamente, estabelecendo a relação entre o brincar e o aprender a aprender.

No jogo do dominó, a turma se mostrou muito interessada, pois iria compreender melhor como ocorre o processo básico relacionado ao fenômeno da hereditariedade, como características dos pais são passadas para os filhos. A ideia do jogo era mostrar, na prática, como acontece a meiose. Dessa forma, entende-se que os conhecimentos da Genética associados ao ensino da Biologia da Reprodução no contexto escolar e social, podem tornar os conteúdos científicos escolares dotados de significado, aplicação e riqueza de exemplos da vida cotidiana (KLAUTAUGUIMARÃES et al., 2009).

O segundo questionário foi aplicado duas semanas após o término dos jogos e, com isso, pôde-se perceber que os conteúdos passados durante os jogos foram aprendidos e fixados pelos alunos. Isso foi comprovado por meio da comparação de resultados entre o primeiro e o segundo questionários, observando-se uma mudança significativa. Outro elemento que contribuiu para o sucesso do Projeto foi a interação aluno-aluno e professor-aluno, proporcionado pelas dinâmicas.

Percebeu-se que as dúvidas dos alunos detectadas no primeiro questionário foram minimizadas após a aplicação dos jogos. Os alunos,, nesse segundo momen- 
to, entenderam e fixaram os conceitos de Genética, pois, mesmo depois de algum tempo após a aplicação do Projeto, eles ainda se lembravam dos conteúdos desenvolvidos.. Isso mostra que eles não decoraram e, sim, aprenderam com os jogos.

O problema está em saber como os professores encaram o lúdico em suas atividades de ensino, uma vez que muitos deles não o aplicam em sala de aula porque temem perder o controle da turma (HERMAN, 2007). Patrinhani (2001) acredita que, por meio das atividades lúdicas aliadas a um trabalho consciente do professor, o aluno mostra-se mais dinâmico, organizado, atencioso, desinibido, concentrado e ágil em seu raciocínio lógico.

O professor deve saber que, para aplicar o lúdico em suas aulas, ele deve levar jogos que transmitam o conteúdo de forma eficiente. Além disso, que o professor seja capaz de chamar a atenção da turma, mostrando aos seus alunos que não precisam somente do livro e do quadro para aprender.

Pesquisas mostram que as formas como as aulas são ministradas já não chamam mais a atenção dos alunos. Apesar dos esforços, os professores necessitam inovar para melhorar a qualidade de suas aulas. Para isso, eles precisam pensar em como atrair a atenção dos alunos para as aulas e fazer com que eles parem de decorar o conteúdo somente para passar de ano. Os alunos precisam entender os conceitos de uma forma que não complique mais o que já está complicado, pois a Genética é uma matéria com conteúdos de assimilação abstrata, ou seja, os alunos não conseguem visualizar e entender conceitos como, por exemplo, mitose e a meiose ou mesmo, a transcrição. O lúdico é uma forma didática e dinâmica que deixa as aulas mais interessantes e o professor pode aplicar os jogos em sua turma e conseguir não só um melhor rendimento, mas um melhor entendimento desses conceitos.

\section{Conclusão}

Após a aplicação das atividades previstas no Projeto Socioeducativo, concluiu-se que: 
- Os alunos possuíam um conhecimento prévio do assunto, mas com deficiências de entendimento;

- O uso de formas diferenciadas de aprendizagem contribuiu para a melhor fixação de conhecimentos por parte dos alunos;

- Os jogos despertaram o interesse dos alunos pelos conteúdos; e

- As atividades permitiram maior interação entre os alunos e entre os alunos e o professor.

Ao final do Projeto, percebeu-se que os alunos apresentaram melhoras sensíveis quanto ao entendimento dos conceitos básicos de Genética.

\section{The ludic application for the use of learning the content of Genetics}

\section{Abstract}

The concepts covered in the teaching of genetics are generally difficult to assimilate, needing some practices necessary to assist in student learning. Such activities, when applied in a playful manner, complement the theoretical content allowing greater interaction among teacher-student-knowledge, making contributions to the teaching-learning process. This study aimed to present the basic concepts of genetics to high school students in public schools in the Federal District through playful activities, students applied to the third year of high school. The 89 participating students completed a questionnaire to evaluate the role of prior knowledge, on the subject. For the project to be economically viable, the games were made with materials that are found in everyday life and are inexpensive. We applied three games: the game of the karyotype, the DNA kit, the game of dominoes. At the end of the study was administered a questionnaire to check whether students have learned from the games. Thus, the work sought to apply different ways of teaching the content of genetics, in addition to promoting a better relationship between students and student-teacher leaving the classroom more dynamic and relaxed.

Keywords: Teaching methodology. Playful learning. Biology. Genetics. 


\section{Referências}

BOLELI, C. I. Abecedário genético. Disponível em: <http://www.unesp.br/prograd/ PDFNE2004/artigos/eixo10/abecedario.pdf $>$. Acesso em: 13 mar. 2009.

BORGES-NETO, H. Uma classificação sobre a utilização do computador pela escola. In: ENCONTRO NACIONAL DE DIDÁTICA E PRÁTICA DE ENSINO, 11, 1998, Águas de Lindoia, SP. Anais... Águas de Lindoia, SP: ENDIPE, 1998.

BUENO, C. O lúdico como estratégia de aprendizagem. 1999. Trabalho de Conclusão de Curso (Especialização) - Centro de Pós-Graduação, Pesquisa e Extensão da Universidade Tuiuti do Paraná, Curitiba, 1999.

BORTOlOTO, T. M.; FELÍCIO, A. K. C. A produção de jogos didáticos para $o$ ensino de ciências e biologia: uma proposta para favorecer a aprendizagem. 2009. Monografia (Graduação) - Instituto de Biociências da Unesp - Campus de Botucatu. Pró-Reitoria de Graduação - Núcleo de Ensino - Unesp, 2003. Disponível em: <http://www.unesp.br/prograd/nucleo2003/index2002.php>. Acesso em: 13 mar. 2009.

CAMPANARIO, J. M.; MOYA, A. Cómo enseñar ciencias? Pricipales tendencias y propuestas. Enseñanza de las ciencias, Barcelona, v. 17, n. 2, p. 179-192, jun. 1999.

CUNHA, N. H. S. Educação lúdica: técnicas e jogos pedagógicos. 9. ed. São Paulo: Loyola, 2000.

DAGOSTIN, F. P. O lúdico como intermediador criança-aprendizagem. 2004. Trabalho de Conclusão de Curso (Especialização em Psicopedagogia) Universidade Tuiuti do Paraná, Curitiba, 2004.

GADOTTI, M. A organização do trabalho na escola: alguns pressupostos. São Paulo: Ática, 1993.

GIACÓIA, D. R. L. A. Conhecimento básico de genética: concluintes do ensino médio e graduandos de ciências biológicas. 2006. Dissertação (Mestrado em Educação para a Ciência, da Área de Concentração em Ensino de Ciências) Universidade Estadual Paulista, Bauru, 2006.

HAUER, D. O lúdico como elemento de intervenção na dificuldade de aprendizagem. Trabalho de Conclusão de Curso (Pós-Graduação em Psicopedagogia) Universidade Tuiuti do Paraná, Curitiba, 2005. 
HERMAN, A. R. M. A importância do lúdico no processo ensino aprendizagem. 2007. Monografia (Licenciatura em Pedagogia) Centro Universitário de Brasília UNICEUB, Brasília, 2007.

JUSTINA, L. A. D. Ensino de genética e história de conceitos relativos à hereditariedade. 2001. 145 p. Dissertação (Mestrado em Educação) - Universidade Federal de Santa Catarina, Florianópolis, 2001.

JUSTINIANO, B. C. S. et al. Genética: revisando e fixando conceitos. Genética na Escola, v. 2, p. 51-53, 2006.

KLAUTAU-GUIMARÃES, M. N. et al. Combinar e recombinar com os dominós. Genética na Escola, v. 2, p. 1-7, 2008.

MIRANDA, S. No fascínio do jogo, a alegria de aprender. Ciência Hoje, São Paulo, v. 28, n. 168 , p.64-66, 2001.

NUNES, M. J. C.; et al. Implicações da mediação docente nos processos de ensino e aprendizagem de biologia no ensino médio. Revista Eletrônica de Enseñanza de las Ciencias, v.5, n.3, p. 522-533, 2006.

OLENIKI, R. L. M. O lúdico no processo de aprendizagem. 2002. Trabalho de Conclusão de Curso (Especialização em Psicopedagogia) - Universidade Tuiuti do Paraná, Curitiba, 2002.

PATRINHANI, S. L. M. Jogos um jeito novo de aprender. 2001. Trabalho de Conclusão de Curso (Especialização em Psicopedagogia) - Universidade Tuiuti do Paraná, Curitiba, 2001.

POZO, J. I. Teorias cognitivas da aprendizagem. 3. ed. Porto Alegre: Artes médicas, 1998,284 p.

SALIM, D. C. et al. O baralho como ferramenta no ensino de genética. Genética na Escola, v. 1, p. 6-9, 2007.

SANTOS, S. M. P. dos. A ludicidade como ciência. Petrópolis: Vozes, 2001.

VIGOTSKY, L. S. Linguagem, desenvolvimento e aprendizagem. São Paulo: Icone, 1988.

VIGOTSKY, L. S. Psicologia pedagógica. São Paulo: M. Fontes, 2001. 
Univ. Hum., Brasília, v. 8, n. 2, p. 119-144, jul./dez. 2011
Carla Regina de Mendonça dos Santos, Paulo Roberto Queiroz da Silva

WASKO, P. A. et al. Aliando conceitos e criatividade: proposta de dramatização na área de genética e biologia celular para alunos do ensino médio. Genética na Escola, v. 2, p. 34-38, 2007. 